\title{
World Literature is Trans-Imperial: A Medieval and a Modern Approach
}

\section{Christian Høgel*}

Various concepts guide discussions on global literature, not least stransnationalk. The present text advocates, however, for the term trans-imperial, as offering a more correct definition of world literature, or global literature, both in pre-modern and modern times. Imperial spheres build up worlds of strong interconnections, and the languages they employ become privileged languages that may last beyond the time span of a given empire. These imperial spheres with their one central language therefore form the hardest borders for the dissemination of texts, now and then. By being trans-imperial, texts therefore constitute the true global literature. In medieval times trans-imperial texts would comprise especially fable stories, holy texts, philosophy and science, and mirrors of princes. These were the texts most often carried from one imperial sphere, or rather imperial language, to another, through translations. This article, consequently, offers definitions of what constitutes an imperial language. Central to identifying and safeguarding a language and making it perform as an imperial language was the establishment of a grammar and/or a set of canonized texts defining the language, the actual use of it by an empire in running its administration, and the performance of the empire's self-images through it. In many cases, secondary imperial languages - like Greek in the Roman world or Persian in the Caliphate - would hold a lower but still privileged place in the empire's life and communication. Many such secondary imperial languages could then subsequently rise to the status of imperial languages, as several vernacular languages later did from Latin. The text argues that these features, which are probably most clear-cut in a pre-modern context, also hold true in a modern context, and that what we normally refer to as successful national languages (English, French, Spanish, Russian, etc.) were, from early on, imperial rather than national languages, and that their literature, in being global, was trans-imperial.

Keywords: world literature, global literature, empires, nation states, transnational, trans-imperial

The global is everywhere, and in literary studies, as in so many other fields, efforts thrive to find common ground on how to define scopes that are global as well as those that are less than global. From this endeavour spring attempts to delineate the regional, the national or even the continental, and to view the global as the transregional or the transnational. Even the transcontinental comes up in ubiquitous terms such as Eurasia or Afro-Eurasia. We are attempting to readjust concepts that frame our cultural thinking in a world rapidly changing the parameters of geography. In this, literary studies have to some extent been guided by

* Correspondence details: Christian Høgel, University of Southern Denmark, CML, Institute of History, Campusvej 55, 5230 Odense M, Denmark, hogel@sdu.dk. 
historical and political studies, but the field has also developed specific terms of its own such as cosmopolitan and panchoric. ${ }^{1}$ The present text attempts to introduce yet other new term, in the hope that our manifold approaches may contribute to the on-going readjustment. We have come a long way, but we still have much to catch up with, not least in the endeavour to go beyond deeply embedded western/European frameworks and to find a basic vocabulary that will fit all - or at least most - ages and places. Therefore, but also in order to restructure our discussion of the European situation, the term trans-imperial will here be suggested as a quite universal and precise term for defining global or world literature. The term is almost universally applicable, since empires have been part of human society for a very long time and on all continents. That it is also quite precise, even for Europe, will hopefully become clear from the following exposition, which is in no way exhaustive or complete. The possible angles and exceptions in this area of study are simply too many to enable full coverage of the ground. Also, the implications could be vast, and the presentation given here only hopes to further our discussions of some central concepts when dealing with literary culture and global perspectives. Suggestions will be given, while keeping in mind the scope of the material and through the help of the studies by Thomsen, Pollock and Beecroft in particular, ${ }^{2}$ but they will only be accompanied by a limited number of examples, taken from the field of competence of the present writer. It is my hope that this collected effort will constitute yet further steps towards the fulfilment of what Goethe, and others since him, have called world literature. ${ }^{3}$

\section{History and politics: Transregional, transnational}

For quite some time, literary approaches that owe their terminology to historical thinking have gained importance, especially when discussing global perspectives. And, in order to make the global manageable, concepts common to historical and political studies, like regional and transnational, have become commonplace, which, in turn, has contributed immensely to widening the scope in literary studies. ${ }^{4}$ Themes and texts that in earlier scholarship were entrenched within national borders, in terms of their importance in terms of identity, scope, impact, and dependence, have now, in many ways, been released from national interests and agendas, and their interconnectedness across borders is now beginning to get the attention it deserves.

As in historical and political studies (and studies programmes), regional approaches now seem obvious entities for literary enquiry. The Mediterranean is one such region that may be viewed as a literary entity, the Mediterranean allowing for a crosswise maze of interconnections. ${ }^{5}$ Other areas, e.g. Mughal India, are opening up for such approaches. ${ }^{6}$ But the

Beecroft, An Ecology of World Literature. The terms panchoric and cosmopolitan are treated in chapters 2 and 3, respectively.

2 Thomsen, Mapping World Literature; Pollock, The Language of the Gods; Beecroft, An Ecology of World Literature.

3 Auerbach, Philology and ,Weltliteratur', 2-7; Damrosch, What Is World Literature?, 1-36, with ample discussion and reference to Goethe's deliberations on the subject.

4 See e.g. Iriye, Global and Transnational History, chapter 2 (19-35) on the role of historians has particular bearing on the topic discussed here.

5 See the introduction (3-22) and the section >Philology in the Mediterranean (25-116) in Akbari and Mallette, Sea of Languages.

6 Busch, Poetry of Kings, see the introduction. 
regional also has its difficulties when dealing with literature(s), since the links between the languages within a region may be weaker than those that connect them to other areas where the same language is employed. Still, the gains are enormous.

The other most common break-down of the global along historical-political lines is into the transnational. The transnational has the advantage of combining a fundamentally political framework with a perspective on what goes beyond and is not bound by these borders, as literature - together with other cultural features - is apt to be. ${ }^{7}$ Here the ability to cross political borders gives the scholar a tool for assessing how global a text is. In this way, transnational studies have left a decisive imprint on literary studies. Despite these merits, the main problem with the transnational approach is that the former centrality of European literature (or its position to impose this centrality) remains the fundamental basis of the scholarly approaches. In order to present transnational literary studies as a global model, it is still mainly the national division lines of Europe that are adduced to define a nation and to support the case for why transnational studies should be promoted. ${ }^{8}$ The traditional European model of a seemingly close correspondence between linguistic and national borders, in many cases also the matrix for establishing humanistic academic fields, serves as a basis for the construction of a number of other (national) language fields all over the world. And even if this structure was never really true to life, in Europe or elsewhere, and has now, in Europe, been subjected to further demolition with the establishment of the EU, the originally European national model still lurks in the background of the transnational, stressing the importance of nations in defining the global. This is not to say that the importance of national agendas can be neglected. All literary production and exchange today depends heavily on national (or state) structures, not least in terms of orthography and through school curricula.

But defining the global as transnational is a way of upholding a national perspective that seems out of step with modern perspectives. Dante is transnational, because he has inspired writers such as Ben Okri and Orhan Pamuk; Tolstoy because his readers were not, and are not, only found in Russia but all over the world. But here we see the problem arising. If we take Salman Rushdie as an example, we would hardly insist that his being read in the UK or India proves his transnational, global character as a writer. It is because he has reached beyond this that he has become part of world literature. Had Garcia Márquez or even Roberto Bolaño only been read in Latin America and Spain, they would hardly have earned these epithets. Thus, as is also stressed by many scholars, language plays a central role, and translation may in fact be used as a criterion for claiming global renown for an author. World literature is translated literature, one could claim. And this again puts a significant emphasis on the definition of language.

The contention of this text will be that these approaches, though opening up new perspectives, are still missing a central aspect of what has constituted - and still constitutes the global. Literature is hard to contain within regions, since languages often reach beyond them. The concept of nations works best in a Western/European context. And the definition of language puts pressure on translation as the fundamental definition of global literature.

7 Thomsen, Mapping World Literature, 5-32; Domínguez, Circulation in Premodern World Literature, see esp. his use of William of Tyre as an example, 38-41.

8 Thomsen, Mapping World Literature, 106-119, dealing in particular with holocaust writers. 


\section{The language-sociology approach: translation and provinciality}

Another way of looking at all this focuses on the place of production, and on the distinction between the central and the provincial. As stated by Damrosch and others, global literature (or world literature) may be seen as literature that has the power to reach beyond its original area of production. ${ }^{9}$ More specifically, he indicates as global the texts that are received in various translations, making the text "a locus of negotiation« between two (or more) cultures, eventually leading to a new mode of reading that engages us in a world beyond our own. ${ }^{10}$

Here we may respond that translations may contribute on many different levels to such negotiations. Translations between Danish and Norwegian, for example, very often only save the reader from the effort of adjusting to another spelling, whereas translations between Danish and Chinese cross what is to most speakers and readers of the two languages an insuperable barrier. In fact, the Danish-Norwegian example shows that some translations come to life primarily because of national borders, national book-markets, and national orthographies, (and hardly because of any real capacity problem), whereas the Danish-Chinese example indicates the kind of translation that Damrosch would be thinking of. Also, with this linguistic point of view, we are brought back to the issue of states and politically governed languages.

But literary exchange as being fundamental for any notion of world literature may also be perceived even more sociologically. Some texts naturally speak to the wider world, whereas others, whether by design or due to their inherent qualities, continue to be produced and received in smaller circles. Here one might think of oral literature as something that is by nature local or at least less movable in time and space than written texts, but, if this was ever the case, this is certainly no longer so in times with podcasts and youTube. Still, texts that continue to be produced and received only within an enclosed area - of whatever size thrive and will continue to do so, and sociological approaches to culture in general may here fruitfully be applied to literature. One may, for example, insist, as the sociologist Beck does, on the reciprocal need in the exchange between local and global in all types of customs, ways of thinking, political outlook, and personal identity. ${ }^{11}$ This in many ways repeats the model of la cour et la ville in studies of early modern cultural exchange. ${ }^{12}$ One may also attempt to define provincial literature - and also provincial culture in general - in its interplay with global or international literature, as done by Milan Kundera. He sees two types of provincialism: either that of big nations who may feel that they have enough in their own canons, or that of minor nations who simply cannot approach the big world out there, though they may acknowledge its merits. ${ }^{13}$ Others, such as the French literary scholar Casanova, will stress the basically national or somehow local merits of good literature, no matter how globally or internationally it is subsequently received. ${ }^{14}$ In the nomenclature of Alexander Beecroft, this may also be seen as the opposition between epichoric and panchoric literature. ${ }^{15}$ 
But regardless of how we view it, language - and language status - remains a key issue, also in the present context. Whatever is not written today in one of, say, five major languages, especially English, necessarily has to be translated in order to reach an international, or transnational, audience. So writers in these five or so languages have an enormous advantage. Even what is locally produced in these languages has the potential of reaching a global audience without translation. There is also the issue of writers using a language different from their mother tongue, opting instead for another (and perhaps more widely used) national language, for example, or the language of their new residence/national identity. ${ }^{16}$ And finally, we also have to take all of the complicating matters into account when talking of mother tongues: dialects (e.g. of English on various continents), differences between the written and the spoken word, distinctive markers of identity (e.g. when distinguishing between two national versions of basically the same language), etc. And since writers are increasingly becoming conscious of all these features, in the modern world any type of literature may, it seems, be rightfully discussed and studied as part of transnational processes, translations being only one possible criterion.

What we need, therefore, is a model that will - preferably in a universally applicable way - combine the structures involved (especially the political and the linguistic) into a feasible model. The following will suggest one such model, not to supplant others, but to enrich our discussion.

\section{Imperial languages}

Given the restrictions, presented above, on our understanding of what may define global literature, new approaches are needed, and, as we saw above, models that combine a political/ historical approach with a particular attention to language and translation seem to offer the most useful perspectives. However, it is crucial that we make sure to find the best blocks or entities that together form the global. Such combination is, in fact, at the core of the transnational approach but, as we saw, this has certain flaws. Few nations - if, in fact, any - reproduce the nice divisions into overlapping nations and languages which, for practical or political reasons, became the standard model for viewing some major Western countries (Germany, France, Italy, Spain etc.). The truth is that, after centuries of centralized schooling policies, not even these countries that often served as paradigms live up to the languagenation-country scheme. And the transnational model also has problems language-wise. All countries of Latin America bar a few share the same national language, with some nations having several official languages. At what point does Hispanophone literature produced in these countries become transnational? Furthermore we must acknowledge that transnational studies make most sense in areas where nations are well established, and though we may view the world as composed of United Nations, some nations are very young, whereas others have a much longer history. National languages were once perceived, and may in certain places still be perceived, as being the unique possession of that nation and country. But in most cases, things do not conform to this neat scheme. Finally, there were times when no nations existed, at least not nations that - as in our modern perceptions - had gone through the process of state building. All in all, (trans-)national perspectives will only work for studies into the last couple of centuries and only in a restricted way in any place.

16 See e.g. the discussion in Knoop, Ambiguity of Authorship, 14-15. 
Let us now turn to the medieval world, and see if a non-modern approach can bring us any further. No nation states existed in the modern sense in this epoch, even though some scholars have, for example, attempted to see Byzantium as an early proto-nation state. ${ }^{17}$ In fact, talking of medieval national literatures only makes sense because later canonizing processes have transformed texts into the possessions of various languages strongly tied to specific nations and national curricula, forming categories such as 'medieval French literature.. ${ }^{18}$ This in many ways misrepresents medieval reality. The forerunners of what later became national languages were, in the Middle Ages, in most cases spoken and written in more restricted areas and/or in other places than later, and the linguistic and political landscape was, in general, diverse and far from resembling the modern one. Medieval Europe was split into kingdoms, many of which have ceased to exist, ${ }^{19}$ and multi-lingual courts and administrations thrived, making the linguistic situation quite different from what it is now. ${ }^{20}$ Also, high status languages such as Latin, Greek, and Arabic were found in many places alongside spoken and less standardized vernaculars. And even if some of these vernaculars rose to become the standard means of communication of states, the multifariousness of spoken languages in the given areas hardly allows for a national denomination. ${ }^{21}$

All these observations make it hard to speak of anything national, especially linguistically, in the Middle Ages and as a consequence, also of transnational literature. If we turn instead to what could be taken to be global or world literature in that age, we will soon end up focussing on the high-status languages: Latin in the West, Greek in Byzantium, and Arab in the Muslim world (due to the competences of the present writer, these areas will form the central basis of the argument, but parallel cases could be found in Persian, Sanskrit, Chinese, etc.). Languages such as these formed the more international modes of communication, reaching larger readerships than vernacular texts. At the same time, these high-status languages were often holy languages and/or imperial languages. Their position as a holy language they shared with many other languages, e.g. Hebrew, Church Slavonic, and Coptic, whereas their imperial status was either due to a political reality or founded in former ages of expansion and domination. In that sense, in much of medieval Europe Latin could be seen as an imperial language, not primarily because of any immediate reality, but primarily due to its importance dating back to ancient times, when it was the central and codified language of the Roman Empire. And this imperial quality of a language would often persist even beyond and outside imperial contexts, as Latin did in large tracts of Western Europe. Its status as the imperial language lived on for centuries after its codification, gradually less and less supported by a real functioning empire. ${ }^{22}$ In fact, this is a defining trait of what could be called imperial languages, that once their status is ensured through imperial policy, their life span may unlike vernaculars - reach far beyond any political reality. Alternatively, it could continue its life as a secondary imperial language (former imperial languages now in use under new rulers with a new imperial language), as in the case of Persian in large parts of the Muslim world,

8 Gaunt, French Literature Abroad, see esp. 25-26 and 58-59.

19 Davies, Vanished Kingdoms, 729-739.

20 Tyler, Introduction. England and Multilingualism, 1-14.

21 See the approach in Butterfield, The Familiar Enemy, 36-65.

22 Ostler, Empires of the Word only uses the term »imperial languages « for the colonial empires (see ch. 11, suggesting the concept on 380-381; and making it part of his concluding remarks 446-448). 
for example, or as Greek did for centuries in the ancient Roman Empire. ${ }^{23}$ And, as the examples of Greek and Persian show, secondary languages could later rise (again) to the status of imperial languages (in Byzantium and in the Mughal and Safavid Empires, respectively).

The medieval high-status languages are commonly spoken of as holy languages, but if we take a closer look at the imperial nature of these languages, an equally or even stronger core of dynamism may be seen, related to administrative and educational procedures and ideologies that were embedded in the languages and made them useful or even indispensable in establishing or upholding imperial claims and structures. This does not mean that other languages were barred from approaching (and perhaps in the end attaining) such a status. Castilian was introduced as the new educational language in Spain - to the detriment more of Arabic than of Latin -, Slavonic gained importance to the detriment of Greek, etc. ${ }^{24}$ Furthermore, in some periods, rising imperial languages were able to attain a level of importance equal to that of the older and established languages. Persian, and later Turkish, rose to importance alongside Arabic in the Ottoman world, and it may at times be hard to indicate which was the strongest. ${ }^{25}$ The same goes for European vernaculars when coming on a par, in pre-modern centuries, with Latin.

Consequently, religion is not the sole reason why we easily subdivide the medieval world into its Latin, Greek, and Arabic (or Arabo-Persian) parts; old durable or contemporary imperial structures are just as important if not more so. The division between medieval Latin and Greek is a good example, with a shared religion (despite dogmatic differences) but with a sharp division in terms of imperial claims. And grand notions of empire continued to play an important role in all educational and administrative procedures and ambitions. If we may be allowed a gross simplification, the three areas of Latin, Greek and Arabic primarily understood themselves as heirs and continuators of three different empires. At least, a very large segment of their educated elites did so. Through education these people could consider themselves members of a larger and centuries old community, imagined in much the same way that Benedict Anderson described in the case of modern nations. ${ }^{26}$ This community sprang from a shared schooling and the subsequent shared use of an imperial language, and given the conditions of employment of clerks and others, high proficiency in these languages would be a channel for ambitions and professional pride. We may even say - as is clear, for example, from much history writing - that the class trained in these languages would see empire and its language as a field of attraction, as desirable. Also, due to the scarce resources of pre-modern societies, only larger states or empires could create a unified schooling system with an established orthography, standardized communication formulas, and bureaucratic procedures. ${ }^{27}$

23 Lazard, Rise of the New Persian Language, esp. 595-598; see also several contributions in Mullen, Multilingualism in the Graeco-Roman Worlds, esp. the introduction 1-35.

24 Niehoff-Panagiotidis, Übersetzung und Rezeption, 137-218.

25 Woodhead, Ottoman Languages, 152.

26 Anderson, Imagined Communities, 83-112.

27 Crone, Pre-Industrial Societies, see especially her careful treatment of vocational training and education, 95-103. 
This definition, then, stands in some opposition to that of scosmopolitan languages and literatures, a term advocated for by Sheldon Pollock and central to the exposition by Alexander Beecroft. ${ }^{28}$ In Beecroft's definition, cosmopolitan languages are the languages that often follow in the wake of empires and that commonly employ universalizing tropes. This definition seems, however, to reduce the importance of the empires that caused the spread of these languages and literatures and to leave out the way that imperial institutions and practices continued to be part of how these languages were perceived and practised, not least through the reading of canonized texts from past times of imperial glory. ${ }^{29}$ Empires, whether functioning or remembered, had a strong impact on language and literature.

\section{Imperial languages and imperial literature}

So, insisting on the importance of empires and the imprint they leave on practitioners of literature during the life of the empire as well as, possibly, long afterwards, imperial language also becomes central to a definition of various types of literature. For the clearer employment of the term, we here offer a tri-partite definition of an imperial language. To be truly imperial, a language will (1) need to be identifiable through grammars and/or a canon of standard texts (to be used in schools); it will (2) have to be the language used in the administrative running of an empire; and it will (3) be the linguistic code that central persons and institutions of this empire will employ when giving imperial self-representations, i.e. representations of the empire of which they themselves form a part. To give examples, Greek became an imperial language from the third century BCE when its grammar and especially its canonized (mainly Attic) authors were singled out in Alexandria, when the Hellenistic empires began running their administration in (Atticizing Koine) Greek, and when court intellectuals, such as the scholar-poet Kallimachos (ca. 310-240 BCE) and members of his state-paid class of intellectuals, produced literature glorifying their rulers. ${ }^{30}$ Similar processes can be pointed out for Latin and Arabic. Some imperial languages would, from an early point in their history, be based on grammars: Arabic, for example, already with the work of Miskawayh (932-1030 CE). ${ }^{31}$ Others would - like Latin - initially mainly be identifiable through canonized texts. ${ }^{32}$ The literary canons would serve as school texts, enabling all future partakers in the running of the empire to master the imperial language. The canonized set of standard texts could, of course, be supplemented along the way, and in all empires, we see persons close to power whether political or intellectual - working hard on having their writings enter this sphere. Still, there was - and is - in all empires a remarkable veneration for early texts. This ensured the survival of Homer even if not conforming to the later linguistic standards; the same goes for the Latin comedies of Plautus and Terence, and is also witnessed in the focus in Arabic education systems on the pre-Islamic jahiliyya-poetry. ${ }^{33}$

29 Beecroft, An Ecology, 126.

30 Blum, Kallimachos still good on the state sponsoring behind the poets activities, see esp. 95-98.

31 Versteegh, Arabic Language, 60-84.

32 Black, Humanism and Education; on 173-274 the selection of Latin authors is discussed, displaying the clear preponderance of classical (ancient) authors.

33 Crone, Pre-Industrial Societies, 97-101. 
A purely religious understanding of the enormous importance of high-status languages therefore makes little sense. The imperial background is, for example, evident in the translation of the Old Testament, or Hebrew Bible, into Greek, into what became known as the Septuagint. This was a translation from a holy language (Hebrew) into an imperial one, since Greek at this point carried no religious notions for a Jewish community. And if we may believe the letter of Aristeas, a Ptolemaic ruler even instigated the translation enterprise. ${ }^{34}$ Likewise, the use and canonization of a Latin Bible can hardly be seen as disconnected to the imperial status of Latin, ensuring it a wide usage. ${ }^{35}$ And the ensuing retention of Latin was guided by this, and supported through Biblical references, though it was commonly known that the text was a translation. Holiness was an argument, but imperial conditions were the driving force. This drive was known to literary professionals, the actual users of the common means of written (and to some degree oral) high-status communication. Among these, there was a very high degree of self-awareness, and they proudly saw themselves as literati (or holders of paideia, adab etc.), often even if belonging to religious institutions. Intellectual pride went into this, but also personal ambitions. The language had a learned world - and attractive administrative posts - to offer to those who flocked to its schools and in the end successfully performed its arts.

In this medieval world of learning and literature, borders mattered. In the context of medieval Western Afro-Eurasia, the three imperial languages, and their three "empires" were very differently composed, with the Latin as the probably less unified, but literati in all three areas could see themselves as belonging to an imperial reality. And this imagined perception of imperial wholes facilitated specific types of exchange. Within the three areas an extensive exchange of books, personnel, and educated brides (princesses, queens-to-be etc.) took place. In a medieval setting, these were probably the three most important social factors (apart from general schooling) in maintaining a continuous cultural updating within the literary strata of society. The same type of exchange also took place between empires, but only to a much lesser degree. Various reasons may be given - religious, linguistic, even geographic - but the low degree of exchange remains a fact. Cultural exchange across imperial borders - especially in terms of literature - ended up depending on very few but very influential persons and events, on individual translators, on chance gifts of books, on a few (converting) princesses etc. The importance of Emperor Theophilos sending a manuscript containing the writings of Dionysios the Areopagite to France in the year 827 can hardly be overrated. ${ }^{36}$ The interests of Empress Theophanu (ca. 955-91) deeply influenced courtly tastes in Ottonian Germany, just as the writings of Petrus Alphonsi did when he arrived at the English court in 1116 at the latest. ${ }^{37}$ But such cases are not nearly as numerous as those of people circulating within the imperial spheres.

34 Varillas, La edición del libro sagrado, 86-87.

35 On the history of the Latin Bible, see van Liere, 80-109.

36 Signes Codoñer, Emperor Theophilos, 326-329.

37 See the many contributions in Davids, The Empress Theophano, not least 169-264, and Tolan, Petrus Alfonsi and His Medieval Readers, 132-158. 
Another way of demonstrating the importance of imperial borders is by pointing out that a large-scale literary exchange between empires primarily took place as a result of conquest, in newly conquered zones. The best-known large-scale medieval translations between Latin, Greek, and Arabic took place in Syria, Spain, Sicily, or Southern Italy, at periods just after these areas had changed hands. An elite educated in Greek (or at least Greek culture in Syriac) formed the background to the translations of Greek philosophy into Arabic in Syria/Mesopotamia in the eighth-tenth century CE. ${ }^{38}$ Toledo became a hub of Arabic-Latin translators only after Alfonso VI had conquered it in $1085 .{ }^{39}$ From the eleventh century CE Norman kings in Sicily sponsored a rich production of literature in three imperial languages, not least because Greek and Arabic had recently been the means of (self-)representation of Sicilian rulers and could not, without loss, instantly be replaced by a newly introduced Latin. And in the process of gradual shift, translations multiplied..$^{40}$ In this way, large-scale translations between imperial languages mostly took place in newly conquered zones, whereas translations within the empires - say between Latin and French - could lead a continuous life and in most cases independently of conquests.

The issue of imperial languages could also benefit our understanding of the rise of vernaculars. Many of these appeared as new literary languages, because they were promoted and employed by people and rulers who strove for (a separate) imperial status. Multi-lingual courts and multi-lingual literary circles here played decisive roles. Castilian rose to imperial proportions very much on the model of Arabic, as did Slavonic on the model of Greek. ${ }^{41}$ The fundamental importance of the imperial languages in forming the rise and unfolding of vernaculars as multi-functional written languages will be an important topic for future studies. There is a whole dynamic of imperial languages - to be based on the exchange of books, personnel, and princesses as well as on the conquests of learned centres and the rise of vernaculars to imperial status - when trying to account for the large-scale exchange of texts and narratives in the Middle Ages.

\section{Global literature is trans-imperial}

If this - admittedly cursory - large-scale image of languages in the medieval world may be allowed, we may pick up the various ideas from the discussions of modern global literature and see how and whether they may be applied to medieval literary exchange, and then again, collectively, to the modern situation. That translation constitutes the mark of global literature could well be claimed in the case of medieval literature. Multi-layered fable stories, as well as hagiographical tales and romances would, in that case, come quite high up on the list, being frequently translated but also re-contextualized within new language contexts in the Middle Ages. ${ }^{42}$ Also, more learned and philosophical literature as well as holy texts would be among the notable candidates for a medieval global literature. In fact, the most successful texts - those that travelled farthest - may easily be defined as trans-imperial texts, i.e. as texts that not only circulated in their imperially defined (linguistic) world, but transcended the hardest borders into areas of a different imperial language or languages. Such texts are,

38 Gutas, Greek Thought, Arabic Culture, 11-27.

39 Rodríguez Porto, Ruined Landscape.

40 Mallette, The Kingdom of Sicily, 1-16.

41 See, however, the comments in Franklin, Writing, Society and Culture, 12-13.

42 See Cordoni, Barlaam und Josaphat, 5-57; Stoneman et al., The Alexander Romance, part 1. 
for example, the Sanskrit texts that made it to the West (the story of Barlaam and Josafat, or the famous fable compound, the Kalila wa-Dimna, as its title was in Arabic, and more) or the writings of Greek philosophers such as Plato, Aristotle and Galen. ${ }^{43}$ These and others but not Dante, Psellos, or Ibn Battuta - form a true global literature of the Middle Ages, by being trans-imperial. The traditions of Greek philosophy, holy books, fable stories and/or compounds of embedded tales, and/or mirrors of princes (very often featuring Alexander the Great) were the texts that found successful translators, often in newly conquered areas (areas such as Syria and Mesopotamia, Sicily and Toledo). The people that could ensure these texts further circulation in the next empire - the translators - were few, yet their importance was immense, for real bookish intellectual exchange depended heavily on them and some of these translations became fundamental in their new settings. ${ }^{44}$ Empires formed the major blocks of traditions of learning and common linguistic/aesthetic borders, and the translations produced by these people were the global exceptions to that rule. Some examples in the following paragraphs will attempt to further detail the usefulness and applicability of the term trans-imperial.

First, the term trans-imperial may serve to simply denote the wide - in fact, quite global circulation of some texts, in the Middle Ages. When dealing with the breath-taking success of the Buddha story, as found in the version known in the west as Barlaam and Josaphat, we are at pains to put into simple words the process of this distribution. The Barlaam story was known in various versions and languages all the way from India to Iceland (with another Eastern route less covered and perhaps less evidenced), because subsequent translators made the text - or rather a version of it - available in new languages on the way. ${ }^{45}$ Being originally a Buddhist text, it nevertheless shed its direct religious affiliation on the way, becoming a Manichaean, Islamic (rather than Muslim), and Christian text in various versions, and according to the wishes of the translator. ${ }^{46}$ The enormity of time and space in this trajectory are breath-taking, bringing us from a quite eastern point of one continent (India) to the north-western extremity of the next (Norway and Iceland) and covering this ground only over a time span of more than half a millennium. A clear way of indicating the immense popularity of the Barlaam story would be to call it trans-imperial. In the process, the text crossed repeatedly from one imperial language - or sphere dominated by an imperial language - to the next. To call this process transnational, or international, would make little sense, and viewing the various versions only as representatives of their language is a reductive reference system that simply identifies text objects, but does not outline the process. In the big picture, the Barlaam text belongs to a tremendous trans-imperial success of Sanskrit texts (and those in other Indian languages) that reached empires from China to the Latin West, but whereas this literature lost its Buddhist orientation on the way to the west, it reached China (and Japan etc.) mainly as part of a Buddhist reorientation. ${ }^{47}$

43 Gutas, Greek Thought, Arabic Culture, provides an overview in the appendix, 193-196; Gaullier-Bougassas, Trajectoires Européennes Du Secretum Secretorum, 5-25.

44 See Høgel, The Authority of Translators.

45 Cordoni, Barlaam und Josaphat, 53-55; Genequand, Aux sources, 67-77; Smirnova, L’Histoire de Barlaam et Josaphat, 79-112; Alvar Ezquerra, Barlaam y Josafat, 115-128 .

46 On all this, see Cordoni, Barlaam und Josaphat.

47 On the complexities of the actual routes, see Xinjiang, Land Route or Sea Route?, 1-3. 
But calling the transmission of the Barlaam story trans-imperial would only indicate that the text travelled - in some version - from one imperial sphere to others. It does not elucidate whether there was any clear conception of what this implied in the Middle Ages. Even if medieval readers along the vast expanse travelled by the Barlaam story were told of the Indian origins of the narration (at least in the Greek version and as known to al-Nadim in tenth-century Baghdad), they would have little chance of verifying this, of gathering additional information - e.g. about the originally Buddhist thoughts expressed - and would have no idea of how big the readership was in other places. ${ }^{48}$ In fact, though knowing the foreign origins of the story and knowing that literatures existed in other languages, they would have little possibility of approaching these. This was an instance of quite disconnected readership. Thus, if we want to apply the term trans-imperial to various ages and situations, we will have to take the variations into account. The nature of the trans-imperial, and the implications thereof, differ substantially from age to age. Medieval readers could only know of this to a very restricted degree, whereas modern readers have much better opportunities to identify the trans-imperial. And it is also today that we are discussing such matters.

If we take another example of a very successful trans-imperial cluster of texts, collectively designated as Greek philosophy (including its many scientific and technical writings), this would, from another starting point (the eastern Mediterranean), reach a comparable vast area, with subsequent translations making it available to medieval readers from Iceland to India. ${ }^{49}$ And here, again, trans-imperial would work as a means of identifying and further substantiating the process, not least by explaining its success. It is hard to underestimate the importance of Aristotle and others, whose thoughts and pronouncements have guided intellectual discussions in so many imperial settings, but it is important to remember that in no place did this philosophical literature become the fundamental textbooks of the educational system. Medieval philosophical translations were not made to cover a wide-spread need, but were introduced to form a sort of superstructure to a schooling based on simpler texts of another, either religious or otherwise canonical status. This very phenomenon - its function as intellectual superstructure - could be seen as a central parameter in the way Greek philosophy in its various versions formed a trans-imperial commonality. In any case, trans-imperial seems, at least to the present author, to serve better as an indication of this shared praxis and thought world than most other denominations. And even whether working in parallel or chronologically disconnected, surprising similarities can be observed. See e.g. how various names and aspects of Greek medicine may be gathered from Tibetan sources, mirroring how Arabic medicine became known in the Latin tradition..$^{50}$

Turning to yet another example, trans-imperial may also be employed as a term when trying to explain other surprising common features. The success of the Alexander story in Latin, Greek, Persian and many other languages and corresponding places may surprise a modern reader apt to think of Alexander as a Greek/Hellenistic - and by extension, perhaps Roman hero. But the glory of Alexander is found all around the area in which Greek philosophy - in various translations and extensions - thrived. Alexander's role as a pupil of Aristotle added a bit to his renown, but is obviously not the reason why he appears in the Qur'an or even

48 Dodge, The Fihrist of Al-Nadim, 2/717.

49 Mairs, The Hellenistic Far East, 73-75.

50 See Martin, Historical Contact with Tibet, 118-120. 
why he has such a prominent role in the Shahname. ${ }^{51}$ Stories of Alexander clearly reached far beyond the times and places that surviving texts and images corroborate. His story went trans-imperial, and the spread of iconographic or emblematic pointers (in coins and much else) may be of core value here.

Among trans-imperial texts certain genres feature very persistently, not least the ones already mentioned. The Barlaam story includes an abundance of embedded stories, and embedded tales, not least fable tales, many originating in India, are strongly represented among trans-imperial texts. ${ }^{52}$ The embeddedness probably echoes the experience of many tales told orally, and certain texts were carried to new places multi-vocally accompanied by spoken parallels. Also, holy books, often helped along by missionaries or new converts, experienced trans-imperial success. Manichaean books were found from the Mediterranean to China, and the same goes for the Christian Bible, the Qur'an, and many other holy texts, accompanied by a whole set of liturgical and theological writings. ${ }^{53}$ This type of trans-imperial text would often have stronger institutional ties back to the source contexts. Religious institutions would at least attempt to keep up contact with texts and praxis in trans-imperial contexts (thereby challenging imperial systems!). The story of Constantine-Cyril and Methodios, the apostles to the Slavs, shows how a combined attachment to two imperial spheres may lead to dilemmas. ${ }^{54}$ The story of missionaries and new converts are replete with such ties and failed attempts. Not all holy texts that experienced trans-imperial translation can, however, be accounted for in this way. The early Greek translation of the Qur'an was probably the product of an enterprise in the Muslim area, to be used within a Greek context in a world that was only gradually adopting Arabic as the language of administration (and thereby as its new imperial language). ${ }^{55}$ It was then produced as Greek was on the verge of being reduced to a secondary imperial language, soon practically to disappear in the Levant, where it had been the imperial language for more than a millennium..$^{56}$ The translation nevertheless experienced a - restricted - trans-imperial afterlife, being transferred to Constantinople sometime in the second half of the ninth century. And through further distribution, parts of this translation became even more trans-imperial, reaching Italy by the 16 th century. ${ }^{57}$

51 See Chism, Facing the Land of Darkness, 52-54.

52 See the careful discussion of multi-layered frames in Taylor, Frames Eastern and Western.

53 The literature is enormous. On the Nestorian stele, erected in the year 781 CE outside Xi'an, see e.g. Keevak, The Story of a Stele.

54 See Obolensky, Six Byzantine Portraits, ch. 1.

55 On this early translation of the Qur'an and its possible origin, see Høgel, An Early Translation.

56 Further on this, see Sijpesteijn, Shaping a Muslim State, 229-238.

57 Høgel, The Byzantine Panoplia tradition. 


\section{Trans-imperial in a modern context}

The medieval examples given above of trans-imperial texts and the use of trans-imperial as a concept may fruitfully serve in other descriptions of similar processes, and it will here be the contention that the concept of trans-imperial also works for the modern age. If we may again be allowed simplifications in order to approximate an image of larger structures, we can take the European case again. ${ }^{5}$ Early modern Europe saw, in its central and eastern parts, the appearance of heirs to the Byzantine imperial throne, ${ }^{59}$ and later a number of states based (mostly) in Eastern Europe formed empires that expanded east (Russia, Austria-Hungary, the Ottoman Empire). In the West, the rise of strong and more centralized kingdoms meant a relinquishing of the notion of any unified imperial structure, even if the German (Roman) Empire continued its existence in parts. Instead, most of these states (in fact just about all Atlantic nations) eventually acquired overseas empires. Areas of Europe in between these parts (mainly German-speaking, but also Italy) participated in the latter process but only to a very small degree (and with dire consequences for the later power balance in Europe). Despite these differences between East, West, and Central Europe, all these areas began at some point to view themselves as nations and as taking part in building nation states. In all areas, but particularly in the central and eastern parts, this meant a partial breakup of empires, but in the west, the new nations (often only constructed through the suppression of internal minority cultures and languages) were all, at the same time, the central part of an empire - the headquarters, so to speak, of political entities, parts of which were found overseas. ${ }^{60}$

To give an example, Denmark may from the beginning of the nineteenth century have begun to see itself as a nation state, but the kingdom of Denmark reigned over possessions in the Atlantic, in the Caribbean, in Africa, and even in the Indian Ocean that were never included in this national thinking. ${ }^{61}$ This quite closely mirrored the situation in (other) Western European overseas, or colonial, empires that made sure to separate nation building from their imperial roles. ${ }^{62}$ The nation state was a specific and privileged part of an imperial structure that gained enormously in economic and social terms from the exploitation of its "empire" or - to put it more correctly - of the less privileged parts of the empire. The writings of famous Danish authors such as Søren Kierkegaard and H. C. Andersen, who are very often viewed as national authors, should therefore be read in this imperial setting. The writings of H. C. Andersen in particular may be interpreted quite differently when seen in this light, taking the many references to distant empires (China in The Nightingale, Persia in The Shadow, Istanbul in En Digters Bazar etc.) as emulations, as efforts to rise to the same level as these, despite the fairy tale universe and the irony with which these distant worlds are treated in Andersen's narratives. Likewise, the popularity of the writings of Andersen and Kierkegaard in other parts of Europe (and elsewhere) should, in general, be seen as trans-imperial, travelling from a Danish empire to other empires, in Europe and elsewhere. The same, of course, goes for Balzac, Dickens and many other "national« European authors. Whatever literature crossed from one of these seemingly national areas into another, say from England into France, was really crossing imperial borders.

59 Kafescioğlu, Constantinopolis/Istanbul, 1-15.

60 Berger and Miller, Building Nations, see the introduction.

61 Østergård, Nation-Building and Nationalism.

62 Bang and Kolodziejczyk, Elephant of India, the main point being made on 4-5. 
If this x-ray snapshot of modern European states is accepted, whatever in Europe (until the world wars) has been called transnational was in fact trans-imperial. Today, since the founding of the EU, whatever is exchanged in Europe lies within one empire (or a loosely cohering imperial sphere) and is no longer trans-imperial.

\section{Conclusion}

The trans-imperial model offered here will, if accepted, allow for truly comparable analyses across the pre-modern/modern divide, and has the advantage of being just about universally applicable. The idea of imperial languages forming the model for rising vernaculars can be paralleled in a number of colonial settings. The fate of secondary imperial languages - rising to imperial status, disappearing, or remaining secondary - can help steer our discussions on the linguistic developments today. The fate of French, for example, can be seen as that of an imperial language which, since the world wars, has been reduced to a secondary imperial language, whereas the further rise of English can only be explained through the status of the US (facilitated by former British control over colonies etc.). The heavy inclusion of European - especially German - learning into American academia in the mid-twentieth century (and its gradual transformation into English) was directly dependent upon US military interventions in Europe, which, in the aftermath of the Second World War, may be seen as a newly conquered zone. These examples can be further extended to just about all ages of writing and all continents.

With the proposed definition of imperial languages and literatures, at least one clear difference arises between pre-modern and modern literature. In the world of today writers may be operating in the hope of reaching a global audience. No such instant success was possible for pre-modern literature. It took more than half a millennium for the Barlaam story - originally a tale of the Buddha - to cover the geographical distance from India to Norway, through numerous translations and with the complete loss of any notion of authorship. ${ }^{63}$ The Indian origin of the story was, however, retained and the whole issue of what was discarded and what transmitted is of obvious interest. But, the time dimension in itself and the related possibility of authors and audiences having a notion of the processes involved, of the trajectories from which texts and stories arrived, or of the many accumulated voices added up in the tale when reaching them, all call for a deeper understanding of how global - or trans-imperial literature was perceived in a pre-modern setting, so different from our modern perception. Stories of multiple narrators, of embedded tales in Chinese box systems, reflected not only the coming into being of these texts, but also a general perception of how stories travel. ${ }^{64} \mathrm{But}$ any clearer knowledge of belonging to a specific global literary exchange, or to a common appreciation of world literature, would not be possible in the old world.

This is obviously possible in the world of today, and a clear modern expression of a consciousness of belonging to an imperial linguistic universe through a (particularly successful) literary production may be seen in the many formulations by Derek Walcott on the interconnected world behind the very British education that he received. In interviews,

63 Cordoni, Barlaam und Josaphat, 6-8.

64 Taylor, Frames Eastern and Western. 
he expressed how he experienced a richness in belonging to a world that included nations worldwide, such as New Zealand and Egypt. ${ }^{65}$ This world of educated exchange (but also of much else) was the learned and literary sphere of the British Empire (or the Commonwealth), which, like other empires past and present, offered an attractive world of learned exchange and certain career prospects to those who were able to appropriate its modes of communication. There is a side to empire, and thus to imperial languages and imperial literature, that is desirable to intellectuals and authors. Yet, despite Derek Walcott's positive views of this, the European sea, or colonial, empires were in most cases, unlike former and other empires, very reluctant to allow people coming from outside its "headquarters" (the "national" cores in Europe) a real chance of rising to top posts. This lack of flexibility (or racism) has left a severe mark on our perception of empire, especially in Europe and in the US. And despite modern means of transportation (connecting most parts of the world with instant digital contact and personal transportation within a day or two) we are still operating conceptually very much in terms that were defined by the rise of sea empires (primarily the European colonial empires). In the future, these defining borders and concepts may give way to other structures and other ways of analysing literature; but for now, imperial spheres and trans-imperial literature as the fundamentally global should govern our ways of viewing world literature. And within this structure, imperial literary modes have in many cases been seen as enormously attractive, at least by the strata of society that were involved in its production and consumption, and even if we may not recognize the distinctly imperial features of this literature, we certainly enjoy recognizing the global features of trans-imperial world literature.

\section{Acknowledgement}

The work was supported by the Danish National Research Foundation, under grant DNRF102ID.

65 Walcott, interviewed by Bill Moyers on www.youtube.com/watch?v=XrqKsGYgurM (last accessed on 30 August 2018). 


\section{References}

Akbari, S. C. and K. Mallette (eds.), A Sea of Languages. Rethinking the Arabic Role in Medieval Literary History (Toronto, 2013).

Alvar Ezquerra, Carlos, Barlaam y Josafat: tres lecturas, in: Marion Uhlig and Yasmina Foehr-Janssens (eds.), D'orient En Occident. Les Recueils De Fables Enchâssées Avant Les Mille Et Une Nuits De Galland (Barlaam Et Josaphat, Calila Et Dimna, Disciplina Clericalis, Roman Des Sept Sages), (Turnhout, 2014) 115-128.

Anderson, Benedict, Imagined Communities. Reflections on the origin and spread of nationalism (revised edition), (London, 2006).

Auerbach, Erich, Philology and 'Weltliteraturı, translated from German by M. and E. Said, The Centennial Review 13.1 (1969) 1-17.

Auerbach, Erich, Scenes from the Drama of European Literature, translated from German by Paolo Valesio (Minnesota, 1984).

Bang, Peter Fibiger and Dariusz Kolodziejczyk, Elephant of India: universal empire through time and across cultures, in: Peter Fibiger Bang and Dariusz Kolodziejczyk (eds.), Universal Empire: A Comparative Approach to Imperial Culture and Representation in Eurasian History (Cambridge, 2012) 1-40.

Beck, Ulrich, The Cosmopolitan Vision, translated from German by Ciaran Cronin (Cambridge, 2006).

Beecroft, Alexander, An Ecology of World Literature. From Antiquity to the Present Day (London, 2015).

Berger, Stefan and Alexei Miller, Building Nations In and With Empires - A Reassessment, in: Stefan Berger and Alexei Miller (eds.), Nationalizing Empires (Budapest, 2015) 1-30.

Black, Robert, Humanism and Education in Medieval and Renaissance Italy (Cambridge, 2004).

Blum, Rudolf. Kallimachos, The Alexandrian Library and the Origins of Bibliography, translated from German by Hans H. Wellisch (Madison, 1991).

Busch, Allison. Poetry of Kings: The Classical Hindi Literature of Mughal India (New York, 2011).

Butterfield, Ardis, The Familiar Enemy: Chaucer, Language, and Nation in the Hundred Years War (Oxford, 2009).

Casanova, Pascale, The World Republic of Letters, translated from French by M.B. DeBevoise (Cambridge, 2004).

Chism, Christine, Facing the Land of Darkness: Alexander, Islam, and the Quest for the Secrets of God, in: Markus Stock (ed.), Alexander the Great in the Middle Ages: Transcultural Perspectives (Toronto, 2016) 51-75.

Cordoni, Constanza, Barlaam und Josaphat in der europäischen Literatur des Mittelalters. Darstellung der Stofftraditionen - Bibliographie - Studien (Berlin, 2014).

Crone, Patricia, Pre-Industrial Societies: Anatomy of the Pre-Modern World (London, 2003).

Damrosch, David, What Is World Literature? (Princeton, 2003).

Davids, Adelbert, The Empress Theophano: Byzantium and the West at the Turn of the First Millennium (Cambridge, 2002).

Davies, Norman, Vanished Kingdoms. The History of Half-Forgotten Europe (London, 2011).

Dodge, Bayard, The Fihrist of Al-Nadim. A Tenth-Century Survey of Muslim Culture. 2 vols. (New York, 1970). 
Domínguez, César, Circulation in Premodern World Literature: Historical Context, Agency, and Physicality. Primerjalna književnost (Ljubljana) 35.1 (2012) 35-47.

Franklin, Simon, Writing, Society and Culture in Early Rus, C. 950-1300 (Cambridge, 2004).

Gaullier-Bougassas, Catherine, Margaret Bridges, and Jean-Yves Tilliette (eds.), Trajectoires Européennes Du Secretum Secretorum Du Pseudo-Aristote (Xiiie-Xvie Siècle). Alexander Redivivus 6 (Turnhout, 2015).

Gaunt, Simon, French Literature Abroad: Towards an Alternative History of French Literature, Interfaces. A Journal of Medieval European Literatures 1 (2015) 25-61 (see riviste. unimi.it/interfaces/article/view/4938).

Genequand, Charles, Aux sources de la légende de Barlaam: le calife et l'ascète, in: Marion Uhlig and Yasmina Foehr-Janssens (eds.), D'orient En Occident. Les Recueils De Fables Enchâssées Avant Les Mille Et Une Nuits De Galland (Barlaam Et Josaphat, Calila Et Dimna, Disciplina Clericalis, Roman Des Sept Sages), (Turnhout, 2014) 67-77.

Gutas, Dimitri, Greek Thought, Arabic Culture: The Graeco-Arabic Translation Movement in Baghdad and Early 'Abbäsid Society (2nd-4th/8th-10th Centuries) (London, 1998).

Howe, Stephen, Empire. A Very Short Introduction (Oxford, 2002).

Høgel, Christian, An Early Anonymous Greek Translation of the Qur'ān. The Fragments from Niketas Byzantios' Refutatio and the Anonymous Abjuratio, Collectanea Christiana Orientalia 7 (2010) 67-120.

Høgel, Christian, The Authority of Translators. Vendors, Manufacturers, and Materiality in the Transfer of Barlaam and Josaphat along the Silk Road, forthcoming.

Høgel, Christian, The Byzantine Panoplia tradition and the Greek Qur'àn translation in the Latin West, forthcoming.

Iriye, Akira. Global and Transnational History. The Past, Present, and Future (Basingstoke, 2013).

Kafescioğlu, Çiğdem, Constantinopolis/Istanbul. Cultural Encounter, Imperial Vision, and the Construction of the Ottoman Capital (Pennsylvania, 2009).

Kaldellis, Anthony, Hellenism in Byzantium. The Transformations of Greek Identity and the Reception of the Classical Tradition (Cambridge, 2007).

Keevak, Michael, The Story of a Stele: China's Nestorian Monument and Its Reception in the West, 1625-1916 (Hong Kong, 2008).

Knoop, Christine Angela, Kundera and the Ambiguity of Authorship (London, 2011).

Kundera, Milan, The Curtain. An Essay in Seven Parts (London, 2007).

Lazard, Gilbert, The Rise of the New Persian Language, in: R. N. Frye (ed.), The Cambridge History of Iran IV. The Period from the Arab Invasion to the Saljuqs (Cambridge, 1975) 595-632.

Mairs, Rachel, The Hellenistic Far East. Archaeology, Language, and Identity in Greek Central Asia (Oakland, 2014).

Mallette, Karla, The Kingdom of Sicily, 1100-1250: A Literary History (Philadelphia, 2005).

Martin, Dan, Greek and Islamic Medicines' Historical Contact with Tibet: A Reassessment in View of Recently Available but Relatively Early Sources on Tibetan Medical Eclecticism, in: Anna Akasoy, Charles Burnett and Ronit Yoeli-Tlalim (eds.), Islam and Tibet - Interactions Along the Musk Routes (London, 2016) 117-144.

Martinez-Gros, Gabriel, Brève histoire des empires. Comment ils surgissent, comment ils s'effondrent (Paris, 2014).

Mullen, Alex (ed.), Multilingualism in the Graeco-Roman Worlds (Cambridge, 2012). 
Niehoff-Panagiotidis, Johannes, Übersetzung und Rezeption: Die ByzantinischNeugriechischen und Spanischen Adaptionen von Kalila Wa-Dimna (Wiesbaden, 2003).

Obolensky, Dimitri, Six Byzantine Portraits (Oxford, 1988).

Ostler, Nicholas, Empires of the Word. A Language History of the World (London, 2005).

Østergård, Uffe, Nation-Building and Nationalism in the Oldenburg Empire, in: Stefan Berger and Alexei Miller (eds.), Nationalizing Empires (Budapest, 2015) 461-510.

Pollock, Sheldon, The Language of the Gods in the World of Men. Sanskrit, Culture, and Power in Premodern India (Berkeley, 2009).

Rodríguez Porto, Rosa, Ruined Landscape: Images and Mirages in the Study of Castilian Manuscript Production (1284-1369), Journal of Spanish Cultural Studies 17 (2016) 221237.

Smirnova, Victoria, L'Histoire de Barlaam et Josaphat: transformations et transpositions d'un recueil de fables enchâssées dans la littérature exemplaire, in: Marion Uhlig and Yasmina Foehr-Janssens (eds.), D'orient En Occident. Les Recueils De Fables Enchâssées Avant Les Mille Et Une Nuits De Galland (Barlaam Et Josaphat, Calila Et Dimna, Disciplina Clericalis, Roman Des Sept Sages), (Turnhout, 2014) 79-112.

Signes Codoñer, Juan, The Emperor Theophilos and the East, 829-842. Court and frontier in Byzantium during the last phase of Iconoclasm (Farnham, 2014).

Sijpesteijn, Petra M., Shaping a Muslim State. The World of a Mid-Eighth-Century Egyptian Official (Oxford, 2013).

Stoneman, Richard, Kyle Erickson, and Ian Netton (eds.), The Alexander Romance (Groningen, 2012).

Taylor, Barry, Frames Eastern and Western, in: Marion Uhlig and Yasmina Foehr-Janssens (eds.), D'Orient en Occident: Les receuils de fables enchâssés avant les Mille et Une Nuits de Galland (Barlaam et Josaphat, Calila et Dimma, Disciplina Clericalis, Roman Des Sept Sages), (Turnhout, 2014) 23-40.

Thomsen, Mads Rosendahl, Mapping World Literature. International Canonization and Transnational Literatures (New York, 2008).

Tolan, John Victor, Petrus Alfonsi and His Medieval Readers (Florida, 1993).

Tyler, Elizabeth M., Introduction. England and Multilingualism: Medieval and Modern, in: Elizabeth M. Tyler (ed.), Conceptualizing Multilingualism in England C. $800-$ C. 1250 (Turnhout, 2011) 1-13.

Uhlig, M., and Y. Foehr-Janssens (eds.), D'orient En Occident. Les Recueils De Fables Enchâssées Avant Les Mille Et Une Nuits De Galland (Barlaam Et Josaphat, Calila Et Dimna, Disciplina Clericalis, Roman Des Sept Sages), (Turnhout, 2014).

van Liere, Frans, An Introduction to the Medieval Bible (Cambridge, 2014).

Varillas Sánchez, Isabel, La edición del libro sagrado: El ’paradigma alejandrino< de Homero al Shahnameh, Interfaces 4 (2017) 85-102.

Versteegh, Kees, The Arabic Language (Edinburgh, 1997).

Walcott, Derek, interviewed by Bill Moyers on www.youtube.com/watch?v=XrqKsGYgurM (last accessed December 21, 2017)

Woodhead, Christine, Ottoman Languages, in: Christine Woodhead (ed.), The Ottoman World (Oxford, 2011) 143-158.

Xinjiang, Rong, Land Route or Sea Route? Commentary on the Study of the Paths of Transmission and Areas in Which Buddhism Was Disseminated During the Han Period, SinoPlatonic Papers 144 (2004) 1-32. 